Acta Theriologica 38 (3): 291 - 296, 1993.

PL ISSN $0001-7051$

\title{
Metabolic rate in Pitymys subterraneus of two coat-colour morphs
}

\author{
Marek GĘBCZYŃSKI and Elwira SZUMA*
}

\begin{abstract}
Gębczyński M. and Szuma E. 1993. Metabolic rate in Pitymys subterraneus of two coat-colour morphs. Acta theriol. 38: $291-296$.

Basal metabolic rate (BMR) of the European pine vole Pitymys subterraneus (de Sélys-Longchamps, 1836) with typical black agouti coat colour $(A)$ is $2.78 \mathrm{cc} \mathrm{O}_{2} \mathrm{~g}^{-1}$ $\mathrm{hr}^{-1}$, and in voles with diluted fur pigment $(D)$ it is $3.06 \mathrm{cc} \mathrm{O}_{2} \mathrm{~g}^{-1} \mathrm{hr}^{-1}$. The difference of BMR between the voles of $A$ and $D$ morphs is not significant. Resting metabolic rate $(\mathrm{RMR})$ was determined at ambient temperatures $\left(\mathrm{T}_{\mathrm{a}}\right)-10^{\circ} \mathrm{C}, 0^{\circ} \mathrm{C}, 6^{\circ} \mathrm{C}, 12^{\circ} \mathrm{C}, 24^{\circ} \mathrm{C}$ and $30^{\circ} \mathrm{C}$. P. subterraneus of $A$ morph decrease RMR from 9.21 (at $-10^{\circ} \mathrm{C}$ ) to $4.80 \mathrm{cc}$ $\mathrm{O}_{2} \mathrm{~g}^{-1} \mathrm{hr}^{-1}$ (at $30^{\circ} \mathrm{C}$ ) while the voles of $D$ morph decrease RMR from 10.43 to $4.01 \mathrm{cc}$ $\mathrm{O}_{2} \mathrm{~g}^{-1} \mathrm{hr}^{-1}$, respectively. The differences of RMR between the voles of $A$ and $D$ morphs are significant at $\mathrm{T}_{\mathrm{a}}-10^{\circ} \mathrm{C}, 0^{\circ} \mathrm{C}, 6^{\circ} \mathrm{C}, 24^{\circ} \mathrm{C}$, and $30^{\circ} \mathrm{C}$. Maximum oxygen consumption rate $\left(\mathrm{VO}_{2} \mathrm{NA}\right)$, after injection of noradrenaline, is not dependent on $\mathrm{T}_{\mathrm{a}}$ (measurements were made at $-10^{\circ} \mathrm{C}, 0^{\circ} \mathrm{C}, 12^{\circ} \mathrm{C}$ and $24^{\circ} \mathrm{C}$ ). It equals $8.96 \mathrm{cc} \mathrm{O}_{2} \mathrm{~g}^{-1} \mathrm{hr}^{-1}$ in $P$. subterraneus of $A$ morph and $10.18 \mathrm{cc} \mathrm{O}_{2} \mathrm{~g}^{-1} \mathrm{hr}^{-1}$ in the voles of $D$ morph, and the difference is significant.
\end{abstract}

Institute of Biology, Warsaw University, Branch in Białystok, Świerkowa 20B, 15-950 Białystok, Poland

Key words: Pitymys subterraneus, coat colour morphs, basal and resting metabolic rates, thermoregulation, maximum oxygen consumption

\section{Introduction}

Mammalian coat colour depends on a large number of genetic and environmental factors (Searle 1968). Particular colour morphs, depending on environmental conditions, may play different roles in populations. E.g. melanistic Sciurus carolinensis survive better under harsh climatic conditions; they have lower heat losses and lower basal metabolic rate in comparison to grey ones (Innes and Lavigne 1979). Differences in body weight and mortality as well as in oxygen consumption rate have been observed among three coat-colour morphs of Microtus oeconomus (Krivosheev et al. 1983). Diluting mutants connected with $P$ and/or $D$ series of alleles (Searle 1968, Silvers 1979) may show deep morphological and/or physiological pleiotropic effects. For instance, the dilution of coat pigment in the mouse affects the inner ear, tending to remove the otoliths from the utriculus. Other diluting genes cause sterility in hamsters. Extreme dilution may be combi-

*Present address: Mammal Research Institute, Polish Academy of Sciences, 17-230 Białowieża, Poland 
ned with blood anomalies in mink and cattle as well as in humans (cited after Searle 1968).

We are unaware of data dealing with the relationship between dilution of coat colour and metabolic rate. This study therefore addressed the comparison of metabolism and thermoregulation in European pine voles Pitymys subterraneus (de Sélys-Longchamps, 1836) of normal coat colour and the morph with diluted pelage pigment.

\section{Material and methods}

The wild type of $P$. subterraneus in eastern Poland is black agouti. A breeding colony of this species (here called $A$ morph) has been kept for over 25 years in the laboratory of the Mammal Research Institute PAS at Białowieża (Buchalczyk 1961). During that period a line of differently pigmented $P$. subterraneus appeared in the colony. Individuals of the line show coat color dilution, and have pink eyes ( $D$ morph). The dilution alleles affect the intensity of coat and eye colour. It is claimed (Searle 1968) that they do it through a clumping of pigment granules so that a black fur appears grey. Detailed genetic background of the colour dilution in P. subterraneus has not been determined yet.

Body weight of $D$ voles is $8.5 \mathrm{~g}$ at $22 \mathrm{nd}$ day after birth, while in $A$ voles it is $10.1 \mathrm{~g}$ at the same age. Some events in morphological development (e.g. separation of digits, opening of acoustic meatus and eyes) take place about one day earlier in agouti voles than in the $D$ morph individuals (Misiejuk 1984). We also observed, when handling the voles, that individuals of $D$ morph are more agressive than the others.

The European pine voles of both morphs originated from laboratory stock and both were kept under the same laboratory conditions, i.e. $\mathrm{T}_{\mathrm{a}} 18-22^{\circ} \mathrm{C}$ and natural light regime. Oxygen consumption was measured in adult voles in a closed-type respirometer (Górecki 1975). Basal metabolic rate (BMR) was measured at $\mathrm{T}_{\mathrm{a}}=30^{\circ} \mathrm{C}$; before the run voles were deprived of food for two hours. Measurements lasted for 30 minutes, with the registration at every two minutes. The lowest values, not fewer than three, were taken into calculations. Resting metabolic rates (RMR) were determined during one-hour periods, and the animals were not fasted before the measurements. RMRs were run at ambient temperatures of $-10^{\circ} \mathrm{C}, 0^{\circ} \mathrm{C}, 6^{\circ} \mathrm{C}, 12^{\circ} \mathrm{C}, 18^{\circ} \mathrm{C}, 24^{\circ} \mathrm{C}$, and $30^{\circ} \mathrm{C}$. Maximum oxygen consumption $\left(\mathrm{VO}_{2} \mathrm{NA}\right.$ ) was determined in non-fasted voles, after injection of noradrenaline, at ambient temperatures $-10^{\circ} \mathrm{C}$, $0^{\circ} \mathrm{C}, 12^{\circ} \mathrm{C}$, and $24^{\circ} \mathrm{C}$. Noradrenaline (NA) was injected intramuscullary in a dose according to Heldmaier's (1971) formula:

$$
\ln \mathrm{NA}(\mathrm{mg} / \mathrm{kg})=1.82-0.458 \ln W \text {, }
$$

where $W$ is body mass in $\mathrm{g}$. The measurements lasted for 45 minutes with registration of oxygen consumption every $90 \mathrm{sec}$.

Regressions of oxygen consumption versus ambient temperature were computed by the method of least squares. Regression coefficients were compared by $t$-test (Zar 1984). The statistical significance of differences between group means were tested by ANCOVA - with two factors (RMR and $\mathrm{VO}_{2} \mathrm{NA}$ ) or one (BMR) - and $\log / \log$ body mass as the covariate.

\section{Results and discussion}

\section{Basal metabolic rate}

Oxygen consumption rate measured under basal conditions in $P$. subterraneus of $A$ morph did not statistically differ from those in the voles of $D$ morph. When 
Table 1. Basal metabolic rate (BMR) in P. subterraneus of two coat colour morphs determined at ambient temperature $30^{\circ} \mathrm{C}$. $A$ - voles with black coat colour (agouti), $D$ - voles with diluted colour of pelage and pink eyes, $n$ - number of voles examined.

\begin{tabular}{lcc}
\hline & \multicolumn{1}{c}{$A$} & $D$ \\
\hline$n$ & 8 & 7 \\
Body mass g $\pm \mathrm{SD}$ & $17.8 \pm 1.0$ & $15.2 \pm 1.2$ \\
$\mathrm{cc} \mathrm{O}_{2} \mathrm{hr}^{-1} \pm \mathrm{SD}$ & $2.78 \pm 0.36$ & $3.06 \pm 0.28$ \\
$\mathrm{~kJ} \mathrm{animal}^{-1}$ day $^{-1}$ & 23.87 & 22.43 \\
\hline
\end{tabular}

oxygen consumption values were calculated in $\mathrm{kJ}$ (assuming that $1 \mathrm{cc} \mathrm{O}_{2}$ equals $20.10 \mathrm{~J})$ per animal per day, and it appeared slightly higher in $A$ voles than in $D$ voles (Table 1), but the differences are not significant.

The basal metabolic rate in wild $P$. subterraneus has previously been determined (23.58 kJ/day, Gębczyński 1964), and it is close to BMR values as measured in $P$. subterraneus of $A$ and $D$ morphs. In the North American pine vole $P$. pinetorum, BMR equals $23.88 \mathrm{~kJ} /$ day (after Koteja and Weiner 1993). A number of other small rodent species present similar BMR levels (see Koteja and Weiner 1993). In melanistic Sciurus carolinensis lower BMR than in the grey morph was observed in winter, but no such differences were found between the colour morphs in summer pelage (Innes and Lavigne 1979).

\section{Resting metabolic rate}

Both morphs of $P$. subterraneus demonstrated different thermoregulatory reactions (Fig. 1). The differences between the morphs depends on the temperature level. Below $18^{\circ} \mathrm{C}$ the metabolic rate changed sharply. The decrease of oxygen consumption between $\mathrm{T}_{\mathrm{a}} 18^{\circ} \mathrm{C}$ and $-10^{\circ} \mathrm{C}$ in the voles of $A$ morph is $0.24 \mathrm{cc} \mathrm{O}_{2} \mathrm{~g}^{-1}$ $\mathrm{hr}^{-1} \times$ deg., while it is $0.32 \mathrm{cc} \mathrm{O}_{2} \mathrm{~g}^{-1} \mathrm{hr}^{-1} \times$ deg. in $D$ morph. There are no changes in RMR among $\mathrm{T}_{\mathrm{a}} 18^{\circ} \mathrm{C}$ and $30^{\circ} \mathrm{C}$ in $A$ morph, and in $D$ morph it is $0.06 \mathrm{cc} \mathrm{O}_{2} \mathrm{~g}^{-1}$ $\mathrm{hr}^{-1} \times$ deg., only. The differences in oxygen consumption between the two morphs at $\mathrm{T}_{\mathrm{a}}-10^{\circ} \mathrm{C}, 0^{\circ} \mathrm{C}, 6^{\circ} \mathrm{C}, 24^{\circ} \mathrm{C}$, and $30^{\circ} \mathrm{C}$, are significant, while those at $\mathrm{T}_{\mathrm{a}} 12^{\circ}$ and $18^{\circ} \mathrm{C}$ are not.

Body temperature $\left(\mathrm{T}_{\mathrm{b}}\right)$ in the European pine vole of the both coat-colour morphs were measured independently of RMRs runs. The $\mathrm{T}_{\mathrm{b}}$ shows that at ambient temperature $12^{\circ} \mathrm{C}$ the voles are normothermic and do not differ from the animals measured immediately after removing from their nest. At $\mathrm{T}_{\mathrm{a}} 2^{\circ} \mathrm{C}$ there is a significant $(p<0.01)$ decrease of $\mathrm{T}_{\mathrm{b}}$ in agouti, and even deeper $(p<0.001)$ in diluted morphs (Table 2).

In $M$. oeconomus oxygen consumption at $\mathrm{T}_{\mathrm{a}} 20^{\circ} \mathrm{C}$ is significantly higher in dark colour morph voles in comparison to light and intermediate ones, while at $\mathrm{T}_{\mathrm{a}} 2^{\circ} \mathrm{C}$ dark and intermediate morphs show significantly higher metabolic rates than do 


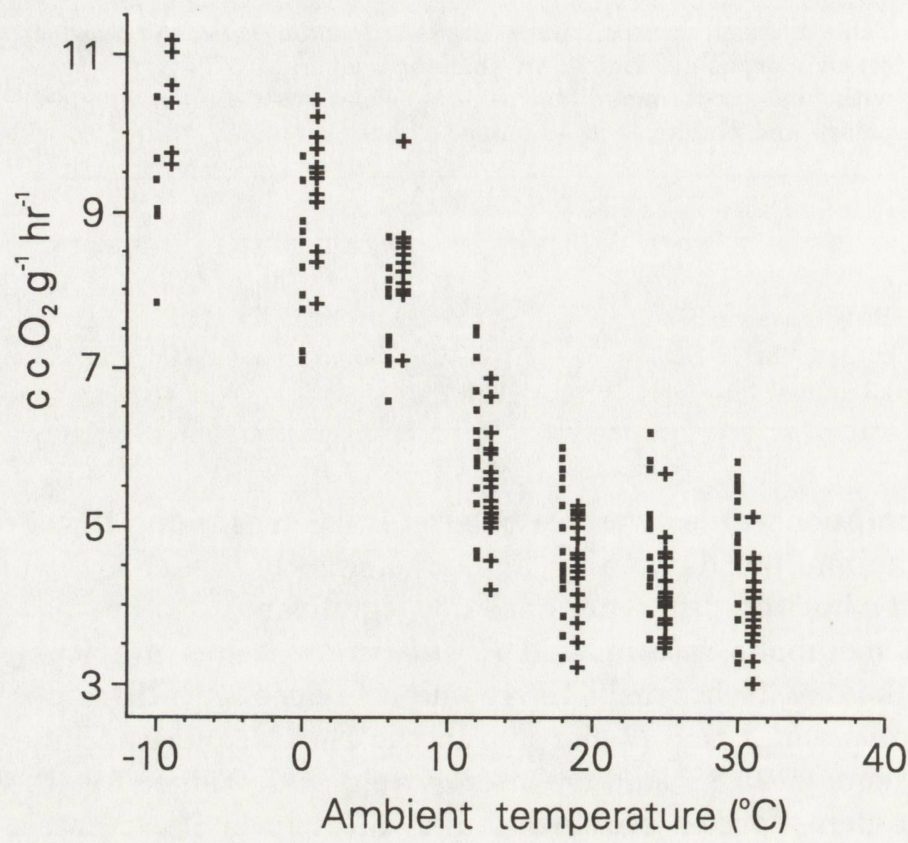

Fig. 1. Resting metabolic rate in Pitymys subterraneus at different ambient temperatures. Regressions of oxygen consumption versus ambient temperature were computed.

Dots: $P$. subterraneus with agouti coat colour $\left(A\right.$ morph): $y=8.17-0.15 x ; r=-0.78\left(\right.$ at $\mathrm{T}_{\mathrm{a}}-10^{\circ} \mathrm{C}$ to $\left.12^{\circ} \mathrm{C}\right)$. Crosses: $P$. subterraneus with diluted coat colour and pink eyes $(D$ morph): $y=8.92-0.24 x$; $r=-0.88$ (at $\mathrm{T}_{\mathrm{a}}-10^{\circ} \mathrm{C}$ to $12^{\circ} \mathrm{C}$ ). Data for voles of $D$ morph have been shifted to the right, for clarity.

Table 2. Body temperature ( $\mathrm{T}_{\mathrm{b}}$ ) in Pitymys subterraneus of two coat-colour morphs. Body temperature was measured rectally with an electric thermometer, with $\mathrm{F} 6$ probe accurate to $0.1^{\circ} \mathrm{C}$. Voles were removed from their nests (nest), or after one hour at $\mathrm{T}_{\mathrm{a}} 12^{\circ} \mathrm{C}\left(12^{\circ}\right)$, or after one hour at $\mathrm{T}_{\mathrm{a}} 2^{\circ} \mathrm{C}$ $\left(2^{\circ}\right) \cdot n$ - number of voles examined. Description of the morphs in Table 1.

\begin{tabular}{lcrc}
\hline $\begin{array}{l}\text { Coat-colour } \\
\text { morph }\end{array}$ & $\begin{array}{c}\text { Nest } \\
\mathrm{SD}(n)\end{array}$ & $\begin{array}{c}12^{\circ} \\
\mathrm{SD}^{\circ}(n)\end{array}$ & $\begin{array}{c}2^{\circ} \\
\mathrm{SD}(n)\end{array}$ \\
\hline$A$ & $37.8 \pm 0.6(70)$ & $37.5 \pm 0.6(66)$ & $36.4 \pm 0.7(70)$ \\
$D$ & $37.6 \pm 0.6(34)$ & $36.8 \pm 1.1(31)$ & $34.2 \pm 1.8(34)$ \\
\hline
\end{tabular}

the voles of light coat colour. In $M$. oeconomus the increase of oxygen consumption between $\mathrm{T}_{\mathrm{a}} 18^{\circ} \mathrm{C}$ and $2^{\circ} \mathrm{C}$ was $0.20,0.18$ and 0.15 cc $0_{2} \mathrm{~g}^{-1} \mathrm{hr}^{-1} \times$ deg., in intermediate, dark and in the light morph voles, respectively (Krivosheev et al. 1983).

In the both morphs of $P$. subterraneus fairly broad thermoneutral zones were found (Fig. 1). However, the metabolism level within the zones is lower in $D$ morph than in the ones of $A$ morph voles. Such a broad thermoneutral zone has been determined in some other small mammals, e.g. Microtus arvalis and Lagurus 
lagurus (Bashenina 1960), as well as in Alticola argentatus and Ochotona daurica (Weiner and Górecki 1981).

The two $P$. subterraneus colour morphs significantly differ $(t$-test, $p<0.001)$ with regard to the slope of their metabolic response calculated for $\mathrm{T}_{\mathrm{a}}$ range $-10^{\circ} \mathrm{C}$ to $12^{\circ} \mathrm{C}$. The elevations of the regression lines are significant $(p<0.002)$ as well.

\section{Maximum metabolic rate}

There was no effect of ambient temperature upon the thermogenic response after NA injection in both colour morphs of the European pine voles. Maximum oxygen consumptions averaged $8.96( \pm 0.87) \mathrm{cc} \mathrm{O}_{2} \mathrm{~g}^{-1} \mathrm{hr}^{-1}$ in $A$ morph, and 10.18 $( \pm 0.97)$ in $D$ morph, respectively. The difference is significant. It suggests that noradrenaline-induced heat production, being an equivalent to physiologically induced non-shivering thermogenesis (Böckler et al. 1982), is higher in P. subterraneus with diluted pelage than in voles having dark coat colour.

Table 3. Maximal oxygen consumption $\left(\mathrm{VO}_{2} \mathrm{NA}\right)$ in $P$. subterraneus of two coat colour morphs, after injection of noradrenaline, at different ambient temperatures. Descriptions of the morphs in Table 1.

\begin{tabular}{|c|c|c|c|c|c|}
\hline & \multicolumn{5}{|c|}{ Ambient temperature $\left({ }^{\circ} \mathrm{C}\right)$} \\
\hline & -10 & & 0 & 12 & 24 \\
\hline \multicolumn{6}{|c|}{ Agouti } \\
\hline$n$ & 6 & & 8 & 8 & 10 \\
\hline $\begin{array}{l}\text { Body mass, } \mathrm{g} \pm \mathrm{SD} \\
\mathrm{cc}_{2} \mathrm{~g}^{-1} \mathrm{hr}^{-1} \pm \mathrm{SD}\end{array}$ & $\begin{array}{c}16.3 \pm 1.1 \\
9.20 \pm 1.00\end{array}$ & $\begin{array}{c}15.1 \\
9.33\end{array}$ & $\begin{array}{l} \pm 0.8 \\
\pm 0.73\end{array}$ & $\begin{aligned} 16.0 & \pm 1.7 \\
8.68 & \pm 0.85\end{aligned}$ & $\begin{array}{c}16.3 \pm 2.3 \\
8.71 \pm 0.88\end{array}$ \\
\hline \multicolumn{6}{|c|}{ Diluted } \\
\hline$n$ & 6 & & 6 & 8 & 12 \\
\hline $\begin{array}{l}\text { Body mass, } \mathrm{g} \pm \mathrm{SD} \\
\mathrm{cc}_{2} \mathrm{~g}^{-1} \mathrm{hr}^{-1} \pm \mathrm{SD}\end{array}$ & $\begin{array}{l}15.5 \pm 1.4 \\
10.45 \pm 0.77\end{array}$ & $\begin{array}{l}16.0 \\
10.31\end{array}$ & $\begin{array}{l} \pm 3.2 \\
\pm 1.03\end{array}$ & $\begin{array}{l}15.0 \pm 1.0 \\
10.26 \pm 0.51\end{array}$ & $\begin{array}{c}16.7 \pm 2.3 \\
9.92 \pm 1.27\end{array}$ \\
\hline
\end{tabular}

Presumably non-shivering thermogenesis enhances survival in cold-acclimated mammals (Jansky 1973), and is negatively correlated with body size (Heldmaier 1971, Weiner 1989). However, both morphs of $P$. subterraneus were kept under the same conditions and their body mass is too small to explain the observed differences in maximal oxygen consumption (Table 3). Therefore the diluted colour mutations in the European pine vole affects some other physiological mechanism. It might be that the same mechanism differentiates RMR of the both morphs, within thermoneutral zone as well as at low ambient temperatures, but does not affect their basal metabolism.

Acknowledgements: The studied European pine voles originated from Mammal Research Institute, Polish Academy of Sciences at Białowieża; where some RMR measurements were obtained. Dr J. Weiner has kindly suggested the methods of statistical analysis and critically commented on an earlier draft of the manuscript. Three anonymous referees are thanked for their remarks. 


\section{References}

Böckler H., Steinlecher S. and Heldmaier G. 1982. Complete cold substitution of noradrenaline-induced thermogenesis in the Djungarian hamster, Phodopus sungorus. Experientia 38: 261 - 262.

Bashenina N. V 1960. Materials on the ontogenesis of thermoregulation in the common field mouse (Microtus arvalis Pall.) and Lagurus lagurus Pall. [In: Fauna and ecology of the rodents. A. N. Formosov, ed]. Publ. House of Moscow Univ., Moscow 6: 111 - 154. [In Russian with English summary]

Buchalczyk A. 1961. Pitymys subterraneus (de Sélys-Longchamps, 1835) under laboratory conditions. Acta theriol. 4: $282-284$.

Gębczyński M. 1964. Effect of light and temperature on the 24-hour rhythm in Pitymys subterraneus (de Sél.-Long.). Acta theriol. 9: 127 - 137.

Górecki A. 1975. Kalabukhov-Skvortzov respirometer and resting metabolic rate measurements. [In: Methods of ecological bioenergetics. W. Grodziński, R. Z. Klekowski and A. Duncan, eds]. Blackwell, Oxford, London, Edinburgh, Melbourne: 310 - 314 .

Heldmaier G. 1971. Zitterfreie Wärmebildung und Körpergrösse bei Säugetieren. Z. vergl. Physiol. 73: $222-248$.

Innes S. and Lavigne D. M 1979. Comparative energetics of coat colour polymorphs in the great eastern grey squirrel, Sciurus carolinensis. Can. J. Zool. 57: 585 - 592.

Jansky L. 1973. Non-shivering thermogenesis and its thermoregulatory significance. Biol. Rev. 48: $85-132$.

Koteja P. and Weiner J. 1993. Mice, voles and hamsters: metabolic rates and adaptive strategies in muroid rodents. Oikos 66: $505-514$.

Krivosheev V. G., Tzvetkova A. A. and Umantzeva N. D. 1983. Polymorphism by fur colour and morpho-physiological differences in colour morphs in a tundra population of Microtus oeconomus. Zool. Z. 62: 1087 - 1096. [In Russian with English summary]

Misiejuk M. 1984. Rozwój postnatalny u darniówek (Pitymys subterraneus) pochodzących z dwóch hodowlanych linii genetycznych. M. Sc. thesis, manuscript. Białystok. [In Polish]

Searle A. G. 1968. Comparative genetics of coat colour in mammals. Logos Press, London: 1 - 308.

Silvers W. K. 1979. The coat colors of mice. A model for mammalian gene action and interaction. Springer Verlag, New York, Heidelberg, Berlin: 1 - 379.

Weiner J. 1989. Metabolic constraints to mammalian energy budgets. Acta theriol. 34: $3-35$.

Weiner J. and Górecki A. 1981. Standard metabolic rate and thermoregulation in five species of Mongolian small mammals. J. comp. Physiol. 145: 127 - 132.

Zar J. H. 1984. Biostatistical analysis. Prentice Hall, Englewood Cliffs, New York: $1-718$.

Received 23 April 1993, accepted 5 October 1993. 